CESIS Electronic Working Paper Series

Paper No. 308

\title{
Survival, Productivity and Growth of New Ventures across Locations
}

\author{
Hans Lööf \\ Pardis Nabavi
}

May, 2013 


\title{
Survival, Productivity and Growth of New Ventures across Locations
}

\author{
Hans Lööf ${ }^{1}$ and Pardis Nabavi
}

First version, October 2012; Revised version, May 2013

\begin{abstract}
We assess the impact of the location of genuinely new ventures and spinoffs on these firms' survival, productivity and growth. The study distinguishes between four different categories of locations: metro cities, metro regions, urban areas, and rural areas. Using a unique database covering more than 23,000 new entrants between 2000 and 2004 in Sweden and observing them for 5 years, several conclusions may be drawn from our study. First, there is a substantial difference in ex-post entry performance between the manufacturing and service sectors. Second, the proposed superiority of start-ups by ex-employees depends on the performance measures and the sector. Third, knowledge and technology intensity of the industry matter for the viability of the new firms.
\end{abstract}

Keywords: Location, New ventures, Survival, Productivity, Growth JEL: L25, L26, M13, O47, R11

\footnotetext{
${ }^{1}$ Centre of Excellence for Science and Innovation Studies (CESIS), Royal Institute of Technology Stockholm, Sweden, Hans.loof@indek.kth.se

${ }^{2}$ Centre of Excellence for Science and Innovation Studies (CESIS), Royal Institute of Technology Stockholm, Pardis.nabavi@indek.kth.se
} 


\section{INTRODUCTION}

Entrepreneurship is recognized as an engine of economic dynamics, and start-ups by exemployees of incumbent firms are found to be a distinctive class of new firms (Agarwal et al. 2004; Klepper and Sleeper 2005; Andersson et al. 2012.) However, a new company is not just affected by inherited experience from other companies via entrepreneurial spawning. Experience and knowledge of technical and organizational solutions, markets, and other factors can also spill over from the geographical environment in the form of industrial clusters, agglomerations, labor mobility and proximity to dominant customers. A large body of literature has examined how aggregate knowledge sources inside a region generate spillovers and affect the outcome of firms located in a region (e.g., Jaffe 1986; Audretsch and Feldman 2004).

Despite a large interest in both performance of new firm formations and the spatial importance of new ventures, there are remarkably few systematic studies on both these factors within the same framework. Our primary contribution is a unique systematic comparison of the survival, productivity and growth of spinoffs and other new firms in different geographical locations. Most previous studies have used samples of new firms or new firms in a specific industry, while our study is based on population data and covers the entire economy except for the primary sector. We study approximately 23,000 Swedish ex-employee start-ups and genuinely new entrants (GNV) in metro-cities, metro-regions outside metro-cities, largecities, and rural areas from the period of 2000 to 2008.

Location-specific benefits can differ both between manufacturing and services and between knowledge-intensive production and other specialties. Therefore, we analyze new firm formation across regions in two categories of manufacturing with distinctly different technology intensities, and two categories of services with distinctly different knowledge intensities. The rich data set allows us to follow the companies throughout the entire critical first five-year period in the market.

In the econometric analysis, we first apply a discrete-time hazard model to study survival. Then, a dynamic panel data approach is used to assess productivity and growth. The paper 
establishes the following regularities. First, spinoffs in services have a significantly higher survival rate than other new ventures, wherever they are located. Among manufacturing firms, only spinoffs outside metro areas are more prone to survive the first five years than genuinely new entrants. Second, manufacturing spinoffs in metro-cities have a superior productivity to that of other new firms in the same sector. In services, spinoffs are more productive than other new ventures across all regions. Third, new manufacturing firms linked to a father firm do not differ in productivity growth compared to other new manufacturers. Concerning services, we find that both spinoffs and other new businesses benefit from presence in metro-cities in terms of productivity growth, regardless of their knowledge intensity. The results for employment growth among new firms are mixed.

The rest of paper is organized as follows. Section 2 provides a brief literature review, section 3 provides data and section 4 provides the model. The results are reported in section 5, and section 6 concludes the paper.

\section{PREVIOUS LITEARATURE}

Mansfield (1962) was one of the first to study new firms' entry processes and their determinants in a systematic way, while Dosi (1988), in contrast to the neoclassical view, discussed the microeconomic variety characterizing new entrants. Jovanovic (1982) represents the earliest attempt to formally model the post-entry evolution of new entrants. The noisy selection model predicts that only efficient firms survive and grow.

More recent research tries to incorporate the space with the analysis. Acs et al. (2007) suggest that the conditions for survival, productivity and growth of heterogeneous newborn firms vary not only with firm- and industry-specific factors but also with location attributes. Regional variations in both survival and survivors' performances might be correlated with particular industry factors such as knowledge and technology intensity (Brixy and Growtz 2007), industry clusters (Saxenian 1994), and a variety of firm-specific factors such as close attachment to a previous employer, managerial capacity and human capital. ${ }^{3}$

\footnotetext{
${ }^{3}$ Wennberg and Lindqvist (2010) find a positive effect of localization, in the form of high concentration of related workers and establishments, on the survival of Swedish entrants in knowledge-intensive industries.
} 
Recent research has documented several regularities in new firm formation with potential impact on firms' futures. About two out of three new founders come from the same region and the same sector as their previous employment or business activity, while the remainder are in-migrating entrepreneurs or young people with no previous job experience (Shane 2000; Renski 2009). People with experience from incumbent firms, people who start a new firm in the same sector and the same region as the parent firm or previous employers are more likely to be successful than leaders of other new firms (Storey 1994; Klepper 2002; Andersson et al. 2012). New firms created by locals are bigger, more valuable and better financed than startups created by non-locals (Michelacci and Silva 2005).

It has also been shown that human capital and specific rather than generic education and skills in economic, managerial, technical and scientific fields increase both the likelihood of survival and the economic performance of new firms (Becker 1964; Brüderl et al. 1994; Almus and Nerlinger 1999; Colombo and Grilli 2005).

The primary motivation to start a new venture has been found to be a predictor of post-entry profitability and growth. The research differs between dynamic factors such as new innovative ideas and more defensive factors such as escape from unemployment (see Vivarelli and Audretsch 1998; Arrighetti and Vivarelli 1999; Andersson and Klepper 2013). The literature suggests that the risk of unemployment and similar motivations for starting a new business are associated with higher death-risk and lower productivity (Pfeiffer and Rize 2000; Andersson and Wadensjö 2006). Because dynamic factors are more frequent in agglomeration areas, the underlying motivation will influence interregional variations in new business survival and growth.

However, few studies have systematically examined geographical variation in survival, productivity and growth among new businesses. One main reason is lack of suitable micro data. In fact, very few countries have databases that allow for creating matched employeremployee data that is suitable for the systematic examination of spatial variations in new firm entry, survival and performance. The three Nordic countries, Denmark, Norway and Sweden, 
are among the few countries where such studies are possible. Portugal and Brazil have similar data, while studies in other countries are performed using second-best data solutions.

Typically, existing studies on interregional variation in the viability of new ventures build on cross-sectional samples or panel data on selected geographical areas, preferably metropolitan economies. Most studies have not been able to confirm the prediction by Hoover and Vernon (1959) that central locations are advantageous for new businesses. See, for instance, Audretsch and Fritsch (1994), Keeble and Walker (1994), Reynolds (1994), Reynolds et al. (1995), Fotopoulos and Spence (1999), Armington and Acs (2002), Rosenthal and Strange (2003), Lee et al. (2004), Fritsch and Mueller (2005), and Feser et al. (2008).

The justifications for rejecting the Hover and Vernon hypothesis include the following: (i) new firms that compete through innovation have a higher risk of failure, and because this type of firm is disproportionately located in the core, large cities will have higher rates of failure than less dense areas (Renski 2009); (ii) complex, sticky and tacit knowledge spillovers are believed to be strongly dependent on proximity (Lamorgenese et al. 2010; Greenstone et al. 2010; Lychagin et al. 2010), but these spillovers will benefit knowledge-intense businesses more than other startups (Campi et al. 2004); and (iii) firms entering in the metropolitan fringe may benefit from the size and density of the nearby area without incurring the same costs (Phelps et al. 2001). Some studies are able to establish a positive link between new firm formation and population size. Grek et al. (2009) show that the market potential as measured by local and external accessibility to gross regional product has a strong, significant impact on the entry of new firms. (See also Hoogstra and van Dijk (2004) and Gabe (2004)). Some studies indicate that spinoffs are more prone to take advantage of agglomerations than other firms (see, for instance, Nicolaou and Birely 2003 and Acs et al. 2009).

The existing study most similar to ours is Renski (2009), which examines variation in entry, survival and growth inside and outside areas in the U.S. Renski finds that new knowledgeintense firms in central cities have higher failure rates but that employment growth is faster than at corresponding firms in other places. The study also reports that suburbs, small cities and rural segments of metropolitan cities tend to be good incubators for new entering firms. 
However, no local milieu favors entrepreneurship across all sectors and performance measures.

\section{DATA AND VARIABLES}

The firm-level data used in this study were originally constructed from audited register information on firm characteristics based on annual reports on firms in Sweden provided by Statistic Sweden (SCB). Based on both firm- and individual-level data, the new firms are classified into two different categories: employee-start ups and genuinely new ventures, which are not directly tied to any existing firms through employment migration.

Following Andersson and Klepper (2013), employee start-ups are recognized by observing the presence of ex-employees at both the parent company and the new firm. The method begins by identifying whether the majority of people in a new firm in a particular year were also a minority in another firm during the previous year. ${ }^{4}$ If the parent firm continues to exist in the year of the new firm's founding, and if the new firm is not a result of a merger, then the start-up firm is considered a spinoff. ${ }^{5}$

If the employees of the new firm were unemployed the previous year, or the majority of employees were not working in a specific firm, these new firms are classified as genuinely new ventures. All new firms with over 10 employees during the first year of operation are dropped to restrict the sample to independent new firms and to avoid capturing the probable effect of outsourcing and mergers and acquisitions. Moreover, new firms with 1 employee (self-employers) are also omitted from the sample.

Our main focus is on the cohorts of new firms founded during the period 2000-2004, and the window of observation is the period 2000-2008. We are thus able to follow the development

\footnotetext{
${ }^{4}$ Firms that were a minority in the parent firm the year before the transition to the new venture but a majority in the new firm the year after the transition are considered to be entrepreneurial spawns or spinouts.

${ }^{5}$ To be considered a spinout, the new venture cannot be a branch of an existing business. Some firms may erroneously be classified as new if they have been inactive for some time or if they have high turnover. With applying two identifiers coming from Business Statistic and statistic Sweden and by tracking each firm during the years prior to their entry (our records date back to 1997), we avoid misclassifying these firms as new.
} 
of each of the new firms for 5 years after their entry. ${ }^{6}$ In our data, we observe a total of 5,195 unique entrants spawned by incumbent firms over the period 2000-2004 and 17,842 unique genuinely new firm entrants. In the first part of the analysis, we use all of the approximately 103,000 observations on these firms to estimate the likelihood of survival in the first five years on the market. The second part of our study considers growth performance, and following the tradition started with Audretsch (1995), the sole focus is on survived firms. In total, 2,095 spinoffs and 5,629 genuinely new firms remained active five years after entry.

In the analysis, we separate the basic sample into four subsamples: firms specializing in high and high-medium manufacturing technology, low and low-medium manufacturing technology, knowledge-intensive services and other services. ${ }^{7}$ The motivation is that a variety of fields of the literature on entrepreneurship, economics of innovation and economic geography explain advantages of firm location with factors such as natural advantages due to path dependency, pecuniary economics related to transportation cost and scale economics, proximity to consumers, suppliers and competitors, access to specialized inputs and specialized workers, technological spillovers and other externalities (this literature includes Marshall 1920, Porter 1990, Krugman 1991, Krugman and Venables 1995, Fujita and Thisse 2002, Acs and Armington 2004, Iammarino 2005 and Lychagin et al. 2010). Location-specific benefits differ between both manufacturing and services and between knowledge-intensive production and other specialties.

We distinguish between four types of locations of the new firms: "metro cities", "metro regions", "urban areas" and "rural areas". Sweden's three metropolitan cities, Stockholm, Gothenburg and Malmö, are classified as metro cities. Metro regions include municipalities where 100 percent of the population live within cities (except for Stockholm, Gothenburg and Malmö) or within a $30 \mathrm{~km}$ distance from these cities. Municipalities with a population of at least 30,000 inhabitants and where the largest city has a population of 25,000 people or more are classified as urban areas. The remainder of the municipalities composes the final category of rural areas. "Metro cities" represent $17 \%$ of the Swedish population. "Metro regions", "urban areas" and "rural areas" represent 18\%, 30\% and 35\% of the population, respectively.

\footnotetext{
${ }^{6}$ Cohort 1: 2000-2004, Cohort 2, 2001-2005...Cohort 5: 2004-2008.

${ }^{7}$ Primary sector is not included in the study. For a detailed description of the classification, see http://epp.eurostat.ec.europa.eu/cache/ITY_SDDS/Annexes/hrst_st_esms_an9.pdf
} 
The distribution of spinoffs and genuinely new firms across industries and regions is displayed in Table 1. The two largest categories of start-ups are knowledge-intensive services and less knowledge-intensive services. Approximately 1 out of 5 new firms may be considered spinoffs.

[Insert Table 1 about here]

Renski (2009) argues that more highly populated areas may be expected to have a larger pool of potential entrepreneurs. However, in accordance with the discussion above, the particular geographical benefit available to a new firm varies with both firm characteristics and industry-specific issues. In Table 1, we calculate a location quotient (LQ), which shows the relative entrepreneurial frequency of a particular region. Therefore, the LQ value equals one when an area type contains a share of all new firms that is equal to the area type's share of the total population. The table reports that new knowledge-intensive services are overrepresented in metro cities, whereas a disproportionately large number of start-ups in low technology manufacturing are located in less populated areas. Because new entrepreneurs tend to remain close to their geographical origin (Costa and Baptista, 2012), we are not surprised that the LQ is almost the same for both genuinely new entrepreneurs and spinoffs from established firms.

Previous literature has shown that start-ups linked to incumbent firms belong to a specific type of new firm formation in terms of productivity and profitability (Agrawal et al. 2004, Klepper 2007, Andersson et al. 2012). Typically, this literature does not consider the relevance of geography. In this paper, we focus on two aspects of new firm formation: the capacity to survive and surviving firms' capacity to grow. The dependent variable in the first part of the study is the duration that a firm remains in the business. The three other dependent variables are the log of value added, the growth of value added and the growth of labor in each period of time.

The key explanatory variables used in this study are interaction variables between location dummies and types of new firms. The reference group in all the regressions comprises genuinely new firms located in "rural areas". 
Our control variables are related to the characteristics of firms. We control for the level of the human capital of new ventures, expressed as the fraction of employees with at least 3 years of university education, physical capital, measured as log annual investment in machineries, size, which is measured as the log value of the number of employees, and ownership, which distinguishes between non-affiliate and members of a domestic group, a domestic multinational group and a foreign multinational group. We also control for the particular 2digit industry to which the new firms belong. All parametric regressions include year dummies. In the growth regressions, we also control for time-invariant non-observed heterogeneity.

Table 2 and 3 report descriptive statistics for manufacturing and service firms. The left section of these tables presents statistics for genuinely new firms, and the right section presents statistics for spinoffs. Both tables show that spinoffs on average are larger in size and have higher value added than other start-ups for each of the four locations. However, no systematic difference in the growth of value added or labor between the two categories of firm is found. The intensity of human capital differs across locations but not between spinoffs and genuinely new entrants. Representing the only exception are knowledge-intensive services in metro cities. In this case, the typical spinoff have somewhat higher fraction of university-educated employees than other firms. Notable is the high level of failure among new firms, and the difference between GNV and spinoffs. In the whole sample, only 35 percent of new entrants with 2-10 employees survived the first 5 years on the market. The descriptive statistics show that ex-employees are substantially more likely to survive.

[Insert Table 2 about here]

[Insert Table 3 about here]

\section{METHODOLOGY}

Two different econometric techniques are implemented to test the hypotheses on the optimal locations of new ventures. To analyze the life duration of new firms, we adopt a proportional 
hazard approach allowing for discrete time intervals. The model used is a complementary loglog model that also controls for unobserved individual effects (Jenkins 2004). Our second approach is a dynamic model testing the causal relationship between location and growth.

Our hazard function estimation is

$$
\lambda_{i t}=1-\exp \left(-\exp \left(\alpha(t)+\beta x_{i t}+u_{i t}\right)\right)
$$

where $\lambda_{i t}$ is the failure rate of a new firm $i$ at time $t, \alpha(\mathrm{t})$ is the baseline failure rate as a faction of time, and $\beta$ is a vector of parameters measuring the influence of explanatory variables $(x)$ on the baseline failure rate. We assume that $u_{i t}$ is the normally distributed error with zero mean.

The general growth model is a standard Cobb-Douglas production function. The data are repeated measurements at different points in time for the same firms. The variables we would like to explain are productivity growth and employment growth. The key interest is to determine the elasticity of productivity and growth and employment growth with respect to different locations. Specified in logarithmic transformation, the basic model may be expressed as follows:

$$
\begin{aligned}
& y_{i t}=\alpha_{i}+\alpha_{j}+\alpha_{t}+\gamma_{1} y_{i, t-n}+\rho_{1} L G N V_{i t}+\rho_{2} L S O_{i t}+\rho_{3} E M P_{i, t-n}+ \\
& \rho_{4} P C_{i, t-n}+\rho_{5} H C_{i, t}+\rho_{6} O W_{i, t}+\varepsilon_{i t} \\
& \Delta y_{i t}=\alpha_{i}+\alpha_{j}+\alpha_{t}+\gamma_{1} y_{i, t-n}+\rho_{1} L G N V_{i t}+\rho_{2} L S O_{i t}+ \\
& \rho_{3} \Delta E M P_{i, t-n}+\rho_{4} \Delta P C_{i, t-n}+\rho_{5} H C_{i, t}+\rho_{6} O W_{i, t}+\varepsilon_{i t}
\end{aligned}
$$

where $y_{\text {it }}$ is the $\log$ productivity of firm $i$ in year $t, \alpha_{i}, \alpha_{j}$ and $\alpha_{t}$ are controls for fixed effects (firm-specific, industry-specific and time-specific, respectively), $y_{i, t-n}$ is lagged $\log$ productivity, LGNV refers to interaction dummies between 4 different locations and GNVs, LSO is a similar interaction variable between location and spinoffs, $E M P$ and $P C$ are the $\log$ values of employment and physical capital, respectively, $\mathrm{HC}$ is the fraction of employees with at least three years of university education, OW represents corporate ownership categorical 
dummies and $\varepsilon$ is the idiosyncratic error term. The EMP variable is omitted in the employment growth regression. In this regression, the dependent variable $y_{\text {it }}$ in equation (3) is labor.

The empirical model that we apply is a dynamic one-step system GMM estimator (Arellano and Bover 1995; Blundell and Bond 2000). To estimate equations 2 and 3, we must classify the variables as endogenous, predetermined, weakly exogenous and strictly exogenous. Based on the literature, we treat the determinants of productivity, human capital, physical capital and firm size (employment) as endogenous regressors. The endogeneity concern reflects the possible correlation between these variables and unobserved productivity shocks.

Our location interaction dummies and all the other dummy variables are all treated as exogenous in the model. It should be noted that the variation over time in LGNV and LSO is almost zero, as most firms do not change their location during the 5-year observation period. Finding a plausible instrument for this almost constant variable is not possible in the present application (for a similar case, see Lychagin, 2010).

\section{RESULTS}

In this section, we present the results of the survival analysis and the performance regressions. Table 4 reports the survival estimates for all new firms created between 2000 and 2004, whereas tables 5-7 present performance results in terms of labor productivity and growth rates of productivity and employment during the first five years of operations for surviving firms. Each of the tables presents results from four different regressions: (i) high and medium-high manufacturing technology, (ii) low and medium-low manufacturing technology, (iii) knowledge-intensive services and, (iv) low and medium knowledge-intensive services.

\subsection{Survival of new firms}

We begin the empirical analysis by considering the survival estimations in table 4 . It should be noted that non-survival is not always a failure. In some cases, companies have disappeared from the market due to acquisition. However, for the vast majority of businesses, shutting down is the result of weak performance. 
The table reports the hazard rate, which is the likelihood that a new entrant will fail at a specific point of time, given that it has survived up to that point. Composing the reference group are genuinely new ventures in rural areas.

To interpret table 4, consider the first column, which presents the results for manufacturing firms in high and medium-high manufacturing. The first row in this column contains the correlation coefficient for the difference between the reference group and GNVs in metro cities. Estimates lower than unity correspond to a higher survival rate than the reference, and estimates larger than unity correspond to a lower survival rate than the reference. The estimate, 0.967, is close to unity and is not significantly different from the reference alternative. The second and third rows also report non-significant results. Rows 4-7 show the estimates for spinoffs (SO). The interpretations are as follows: technology-intensive SOmanufacturing firms outside metro areas are significantly more likely than all other new firms in this category to survive. The point estimate for the average firm in a metro region outside a metro city is also significant, although only at the $10 \%$ level.

Continuing with medium-low and low technology manufacturing, column 2 indicates that starting a GNV in a metro city is a risky project. The likelihood of survival during the first five years is significantly lower compared to market entry in all other locations. With regard to spinoffs, the table reports that start-ups in urban and rural areas are most likely to survive.

The regression results for services show that GNVs in rural areas exhibit a significantly higher viability than GNVs in both high and less high knowledge-intensive sectors. There are several not mutually exclusive interpretations. For instance, it might be a more significant step to start a service business in a rural area, as doing so requires a more detailed analysis of market conditions and the consequences of a failure. Alternatively, the competition is weaker and the firm might survive, even if the profitability is low. Spinoffs in the service sector are more prone to survive across all locations relative to the reference group, but the point estimates indicate that the likelihood of survival decreases with spatial proximity for both knowledge-intensive firms and other services. 
[Insert Table 4 about here]

\subsection{Start-up productivity performance}

Table 5 reports the first of three sets of production function estimates. The performance measure is log value added, controlling for firm size. Previous studies have shown that entrepreneurial ventures spawning from a father firm are superior to other types of newcomers in terms of profitability and productivity. Table 5 adds a spatial dimension to this literature. Looking across the four equations, we see a striking similarity between the two categories of manufacturing firms as well as between the two categories of service firms. The first two columns suggest that only ex-employee manufacturing start-ups in metro cities are more productive than new firms without any ties to a father firm. Spinoffs in other geographical areas are not more productive than other new firms, wherever they are located.

Moreover, we see that the average GNV specializing in high or low technology does not benefit from closeness to proximity areas and potential knowledge spillovers.

The main finding from the two service regressions is that spinoffs are always more productive than other new service ventures. In contrast to manufacturing, there is no metro city premium among either knowledge-intensive spinouts or spinoffs in other service industries. In addition, similarly to manufacturing, we cannot establish any productivity difference between GNV across various locations.

The point estimates for the controls are quite heterogeneous across the table. The most robust results are that value added increases with firm size (not significant for high and medium-high technology firms) and that foreign-owned firms are more productive than domestic new entrants (not significant for low-medium and low technology manufacturing firms). Moreover, with locations controlled for, the results indicate that human capital is more important for services than other factors.

[Insert Table 5 about here]

\subsection{Growth rates}

Table 6 presents the production function estimates for value-added growth. Considering the two manufacturing equations, we observe no significant differences in the estimates across 
locations or types of new firm formation. Spinoffs in metro cities are more productive than other new manufacturing firms, but their growth rates are not superior.

As shown in table 6, estimates for services reveal several interesting results. First, GNVs in metro cities grow significantly faster in terms of value added than GNVs in areas with a lower population density. Second, there exists a premium for location in a metro-city among spinoffs in knowledge-intensive services. Third, for each type of location, spinoffs in both knowledge-intensive services and other services have faster growth rates than corresponding GNVs, although the difference is not significant in some cases.

Table 7 presents regression results for labor growth. Considering both high and medium-high technology manufacturing and knowledge-intensive services, no statistically significant differences in point estimates from the reference alternative are reported. Representing the only exception are knowledge-intensive service spinoffs in rural areas. Here the estimate is negative but only weakly significant. Somewhat surprisingly, the results suggest that spinoffs in low and medium-low manufacturing and located in metropolitan areas are growing more slowly in terms of labor than other firms in this category. Finally, table 7 shows that both GNV and spinoffs in services with low knowledge intensity tend to grow at a higher rate if they are located in metro cities.

\subsection{Test statistics}

Our GMM results are sensitive to both the number of instruments, identification and serial correlation. The bottom sections of tables 5-7 report test statistics on the validity of the regressions. First, we observe that the number of instruments is acceptable across the 12 regressions. The AR (2) statistics indicate that the regressions do not suffer from a correlation problem. Regarding the exogeneity of the instruments, the Hansen test indicates satisfying results in 10 regressions. The results for knowledge-intensive services in table 6 (growth in value added) is close to the critical value, whereas the test indicates that the orthogonality conditions are not fulfilled in table 6 for less knowledge-intensive services. Our overall conclusion on the test statistics is the model specifications are valid. Comparing the dynamic 
GMM results with both OLS and random effects regressions, we find that the general pattern of the results is similar. The main difference is the size of the estimates. ${ }^{8}$

[Insert Table 6 about here]

[Insert Table 7 about here]

\section{CONCLUSIONS}

Previous studies have shown that entrepreneurial spawning from incumbent firms represent a distinguished type of new firm formation. In this paper, we ask whether this is true when the place of location is considered. Approximately 35 percent starters with at least two employees survive the first five critical years on the market.

Several conclusions may be drawn from our study. First, there is a substantial difference in ex-post entry performance between manufacturing and services. Second, the proposed superiority of start-ups by ex-employees depends on the performance measure and sector.. Third, knowledge and technology intensity of the industry matters for the viability of the new firms.

We find that spinoffs in services have a significantly higher survival rate than other new ventures regardless of their location. This finding stands in sharp contrast to new firm formation in manufacturing. In this case, only spinoffs outside metro areas are more likely than genuinely new entrants to survive the first five years of operations. The superiority of spinoffs in manufacturing is limited to firms located in metro cities. In services, spinoffs are more productive than other new ventures across regions with various population densities.

Turning to growth rates, we show that new manufacturing firms linked to a father firm do not grow faster in terms of value added or employment than other new manufacturers. In fact, entrepreneurial spawning in metro cities or metro regions corresponds to the poorest performance in employment growth among start-up firms in low-technology manufacturing. Concerning services, the relations between location and growth is somewhat more complex.

\footnotetext{
${ }^{8}$ For the robustness check, OLS and random effect models are also estimated. The results are available upon request.
} 
All new firms benefit in terms of productivity growth from their local milieu in metro cities. The advantage of proximity is greatest for knowledge-intensive services and spinoffs. No difference in firm size growth with respect to the firms' origin location is found among knowledge-intensive service firms. However, both genuinely new firms and spinoffs in services medium-low or low knowledge intensity tend to have faster employment growth than other firms in this category.

What policy implications may be driven from the study? Spinoffs are often considered a highperforming type of new firm. However, this outperformance represents only one part of the story. We may conclude that the relative performance of ex-employee firms becomes more complex when we include geography into the analysis. We also show that the beneficial effect of the location of new firms differs with regard to the firm's background, industry specification and performance measure used.

\section{Acknowledgements}

The authors would like to thank three anonymous referees and the handling editor for helpful comments and suggestions. 


\section{REFERENCES}

Acs, Z. \& Armington, C., 2004. "Employment Growth and Entrepreneurial Activity in Cities," Regional Studies, Taylor and Francis Journals, 38(8), 911-927.

Acs ZJ, Armington C, Zhang T., 2007. The determinants of new-firm survival across regional economies: The role of human capital stock and knowledge spillover. Papers in Regional Science 86: 367-3911

Acs, Z.J. Audretsch, D.B. Braunerhjelm, P. Carlsson, B., 2009. The knowledge spillover theory of entrepreneurship. Small Business Economics, 32 (2009), pp. 15-30

Agarwal, R., Echambadi, R., Franco, A., Sarkar, M. 2004. Knowledge transfer through inheritance: Spin-out generation, development, and survival. The Academy of Management Journal 47(4), 501-522.

Almus, M. and Nerlinger, E.A. 1999, Growth of New Technology-Based Firms: Which Factors Matter?, Small Business Economics, 13, 141-54.

Andersson, M., Klepper, S, 2013. "Characteristics and performance of new firms and spinoffs in Sweden," Industrial and Corporate Change, Oxford University Press, 22(1), 245-280.

Andersson, M., Baltzopolus, A., Lööf, H. 2012. Firm Strategy and Entreprenurial Spawning. Research Policy. Elevier 41(1), 54-68.

Andersson, P. and Wadensjö, E. 2006, Do the Unemployed Become Successful Entrepreneurs? A Comparison between the Unemployed, Inactive and Wage-Earners, IZA discussion paper no. 2402.

Arellano, M., and Bover, O., 1995. "Another Look at the Instrumental Variable Estimation of Error Component Models." Journal of Econometrics, 68: 29-51.

Armington, C., Acs, Z.J., 2002. "The determinants of regional variation in new firm formation". Regional Studies 36, 33-45.

Arrighetti, A. and Vivarelli, M. 1999, The Role of Innovation in the Postentry Performance of New Small Firms: Evidence from Italy, Southern Economic Journal, 65, 927-39.

Audretsch, D., Fritsch, M., 1994. "The geography of firm births in Germany". Regional Studies 28, 359-365.

Audretsch, D., 1995. Innovation, growth and survival, International Journal of Industrial Organization, 13( 4), 441-457

Audretsch, D.B. and Feldman, M.P. (2004), Knowledge Spillovers and the Geography of 
Innovation, in Henderson, J.V. and Thisse, J.F. (eds.), Handbook of Regional and Urban Economics, Vol. 4, Amsterdam, Elsevier, 2713-39.

Blundell, R., and Bond, S., 1998. "Initial Conditions and Moment Restrictions in Dynamic Panel Data Models.” Journal of Econometrics, 87: 115-143.

Brixy U, Grotz R 2007. Regional patterns and determinants of birth and survival of new firms in western Germany. Entrepreneurship \& Regional Development 19: 293-312

Brüderl, J., Preisendörfer, P. and Ziegler, R. 1992, Survival Chances of Newly Founded Business Organizations, American Sociological Review, 72, 227-42.

Campi, M. T. C., Blasco, A. S., \& Marsal, E. V. 2004. The location of new firms and the life cycle of industries. Small Business Economics, 22 (3-4), 265-281.

Colombo, M.G. and Grilli, L. 2005, Founders' Human Capital and the Growth of New Technology-Based Firms: A Competence-Based View, Research Policy, 34, 795-816.

Costa, C. \& Baptista, R., 2012. "Agglomeration vs. Organizational Reproduction: The Molds Cluster in Portugal," Papers in Evolutionary Economic Geography (PEEG) 1222, Utrecht University, Section of Economic Geography, revised Nov 2012.

Dosi, G. 1988, Sources, procedures and microeconomic effects of innovation, Journal of Economic Literature, 26, 1120-71.

Jaffe, A. B, 1986. "Technological Opportunity and Spillovers of R\&D: Evidence from Firms' Patents, Profits, and Market Value," American Economic Review, American Economic Association, 76(5), 984-1001

Jenkins, S., P., 2004. Survival analysis. Unpublished manuscript, Institute for Social and Economic Research, University of Essex, Colchester, UK.

Jovanovic, B. (1982), Selection and Evolution of Industry, Econometrica, 50, 649-670. NBER working paper n. 9109, Cambridge (Mass.), National Bureau of Economic Research.

Feser E, Renski H, Goldstein H 2008., Clusters and economic development outcomes: An analysis of the link between clustering and industry growth. Economic Development Quarterly 22: 324-344

Fotopoulos, G., \& Spence, N. 1998. Entry and exit from manufacturing industries: Symmetry, turbulence and simultaneity-some empirical evidence from Greek manufacturing industries, 1982-1998. Applied Economics, 30(2), 245-262.

Fritsch, M. 2011. "The effect of new business formation on regional development - Empirical evidence, interpretation, and avenues for the further research", in: Fritsch, M. (Ed), 
Handbook of Research on Entrepreneurship and Regional Development, Edward Elgar, Cheltenham.

Fritsch M, Mueller P 2005., The persistence of regional newbusiness formation activity over time:Assessing the potential of policy promotion programs (working paper). Papers on Entrepreneurship, Growth and Public Policy \#0205

Fujita, M., Thisse, J.F 2002. Economics of agglomeration: Cities, industrial location and regional growth. Cambridge: Cambridge University Press

Gabe TM 2005., Industry agglomeration and investment in rural businesses. Review of Agricultural Economics 27: 89-103

Grek, J, Karlsson C., and Klaesson, J., 2009. Market Potential and New Firm Formation, Working Paper Series in Economics and Institutions of Innovation Nr. 202, Royal Institute of Technology, CESIS - Centre of Excellence for Science and Innovation Studies.

Greenstone, M., Hornbeck, R. and Moretti, E., 2010, “Identifying Agglomeration Spillovers: Evidence from Winners and Losers of Large Plant Openings", Forthcoming in The Journal of Political Economy.

Hoogstra, G. J., \& van Dijk, J. 2004. Explaining firm employment growth: Does location matter? Small Business Economics, 22 (3-4), 179-192.

Hoover, EM, Vernon R 1959., Anatomy of a metropolis: The changing distribution of people and jobs within the New York metropolitan region. Harvard University Press, Cambridge, MA

Iammarino, S. 2005. "An evolutionary integrated view of Regional Systems of Innovation: concepts, measures and historical perspectives". European planning studies, 13 (4). 497519. ISSN 0965-4313

Keeble, D. \& S. Walker (1994), New Firms, Small Firms and Dead Firms: Spatial Patterns and Determinants in the United Kingdom, Regional Studies 28, 411-427

Klepper, 2002 The capabilities of new firms and the evolution of the US automobile industry Industrial and Corporate Change, 11 (2002), pp. 645-666

Klepper, S., Sleeper, S. 2005. Entry by spinoffs. Management Science 51(8), 1291-1306.

Klepper, S. 2007. "Disagreements, spinoffs, and the evolution of Detroit as the capital of the US automobile industry”. Management Science 53(4), 616.

Krugman, Paul, 1991. "Increasing Returns and Economic Geography," Journal of Political Economy, University of Chicago Press, 99(3), 483-99. 
Paul Krugman \& Anthony J. Venables, 1995. "The Seamless World: A Spatial Model of International Specialization," NBER Working Papers 5220, National Bureau of Economic Research, Inc.

Lee SY, Florida R, Acs ZJ 2004., Creativity and entrepreneurship: A regional analysis of new firm formation. Regional Studies 38: 879-891

Lychagin, S., Pinkse, J., Slade, M.E., Van Reenen. J., 2010. "Spillovers in Space: Does Geography Matter?", NBER Working Papers 16188, National Bureau of Economic Research.

Nicolaou, N., Birley, S. 2003. Social networks in organizational emergence: the university spinout phenomenon. Management Science 49(11) 1702-1725.

Mansfield, E. (1962), Entry, Gibrat's Law, Innovation and the Growth of Firms, American

Economic Review, 52, 1023-51.

Marshall, A., 1920. Principles of Economics; An Introductory Volume Macmillan and Co.London, U.K.

Michelacci, C. and Silva, O. 2005, Why so Many Local Entrepreneurs?, CEMFI Working Papern. 0506, Madrid, CEMFI.

Phelps, N. A. 2004. Clusters, dispersion and the spaces in between: For an economic geography of the banal. Urban Studies, 41 (5/6), 971-989.

Pfeiffer, F. and Reize, F. 2000, Business Start-ups by the Unemployed - An Econometric Analysis Based on Firm Data, Labour Economics, 7, 629-63.

Porter, M. 1990. The Competitive Advantage of Nations. New York: Free Press.

Renski, H., 2009. "New Firm Entry, Survival and Growth in the United States.". Journal of American Planning Association, 75 (1), 60-77.

Reynolds P (1994) Autonomous firm dynamics and economic growth in the United States. Regional Studies 28: 429-442

Reynolds, P. D., Miller, B., \& Maki, W. R. (1995). Explaining regional variation in business births and deaths: U.S. 1976-88. Small Business Economics, 7 (5), 389-407.

Saxenian, AnnaLee, 1994, Regional Advantage: Culture and Competition in Silicon Valley and Route 128, Cambridge, MA: Harvard University Press.

Shane, S. 2000, Prior Knowledge and the Discovery of Entrepreneurial Opportunities, Organization Science, 11, 448-69.

Storey, D. 1994, Understanding the Small Business Sector, London, Routledge. 
Vivarelli, M. and Audretsch, D.B. 1998, The Link between the Entry Decision and Post entry Performance: Evidence from Italy, Industrial and Corporate Change, 7, 485-500.

Wennberg K, Lindqvist G 2010., The effect of clusters on the survival and performance of new firms. Small Business Economics 34: 221-241 


\section{Table 1}

Distribution of the 2000-2004 cohorts of genuinely new firms and spinoffs from incumbent firms across industries and regions

\begin{tabular}{|c|c|c|c|c|c|c|c|c|}
\hline & \multicolumn{4}{|c|}{ Manufacturing } & \multicolumn{4}{|c|}{ Services } \\
\hline & \multicolumn{2}{|c|}{$\begin{array}{l}\text { High and medium } \\
\text { high-tech }\end{array}$} & \multicolumn{2}{|c|}{$\begin{array}{l}\text { Medium-low and } \\
\text { Low tech }\end{array}$} & \multicolumn{2}{|c|}{$\begin{array}{l}\text { High knowledge } \\
\text { intensive }\end{array}$} & \multicolumn{2}{|c|}{$\begin{array}{c}\text { Medium and low } \\
\text { knowledge intensive }\end{array}$} \\
\hline & $\begin{array}{l}\text { New } \\
\text { ventures }\end{array}$ & $\begin{array}{l}\text { Location } \\
\text { Quotient }\end{array}$ & $\begin{array}{l}\text { New } \\
\text { ventures }\end{array}$ & $\begin{array}{l}\text { Location } \\
\text { Quotient }\end{array}$ & $\begin{array}{l}\text { New } \\
\text { ventures }\end{array}$ & $\begin{array}{l}\text { Location } \\
\text { Quotient }\end{array}$ & $\begin{array}{l}\text { New } \\
\text { ventures }\end{array}$ & $\begin{array}{l}\text { Location } \\
\text { Quotient }\end{array}$ \\
\hline \multicolumn{9}{|c|}{ Genuinely new firms } \\
\hline Metro cities & 42 & 1,03 & 231 & 1,22 & 2,193 & 2,69 & 3,071 & 1,51 \\
\hline Metro regions & 31 & 0,70 & 114 & 0,56 & 772 & 0,88 & 1,841 & 0,84 \\
\hline Urban areas & 67 & 0,96 & 279 & 0,86 & 1,029 & 0,74 & 3,269 & 0,94 \\
\hline Rural areas & 97 & 1,18 & 472 & 1,24 & 739 & 0,45 & 3,597 & 0,88 \\
\hline Total & 237 & & 1,098 & & 4,733 & & 11,780 & \\
\hline \multicolumn{9}{|l|}{ Spinoffs } \\
\hline Metro cities & 29 & 1,14 & 77 & 1,07 & 830 & 2,83 & 701 & 1,39 \\
\hline Metro regions & 19 & 0,69 & 46 & 0,59 & 249 & 0,79 & 452 & 0,83 \\
\hline Urban areas & 44 & 1,01 & 94 & 0,76 & 372 & 0,74 & 862 & 0,99 \\
\hline Rural areas & 56 & 1,09 & 201 & 1,39 & 247 & 0,42 & 917 & 0,90 \\
\hline Total & 148 & & 418 & & 1,698 & & 2,932 & \\
\hline
\end{tabular}

Notes

The location quotient is a measure of the relative specialization of each area type in new entrants, which is calculated by dividing each area type's share of new firms by its share of the population. 
Table 2

Summary statistics. Mean values and standard deviations. Manufacturing firms

\begin{tabular}{|c|c|c|c|c|c|c|c|c|}
\hline & \multicolumn{4}{|c|}{ Genuinely New Ventures } & \multicolumn{4}{|c|}{ Spinoffs } \\
\hline & $\begin{array}{l}\text { Metro } \\
\text { cities }\end{array}$ & $\begin{array}{r}\text { Metro } \\
\text { regions }\end{array}$ & $\begin{array}{r}\text { Urban } \\
\text { areas }\end{array}$ & $\begin{array}{l}\text { Rural } \\
\text { areas }\end{array}$ & $\begin{array}{r}\text { Metro } \\
\text { cities }\end{array}$ & $\begin{array}{l}\text { Metro } \\
\text { regions }\end{array}$ & $\begin{array}{r}\text { Urban } \\
\text { areas }\end{array}$ & $\begin{array}{l}\text { Rural } \\
\text { Areas }\end{array}$ \\
\hline Survival & 0.28 & 0.38 & 0.42 & 0.40 & 0.52 & 0.51 & 0.61 & 0.58 \\
\hline Value Added, log & $\begin{array}{l}13.80 \\
(1.14)\end{array}$ & $\begin{array}{l}13.66 \\
(1.01)\end{array}$ & $\begin{array}{l}13.76 \\
(1.01)\end{array}$ & $\begin{array}{l}13.79 \\
(0.97)\end{array}$ & $\begin{array}{l}14.38 \\
(1.33)\end{array}$ & $\begin{array}{l}14.14 \\
(1.06)\end{array}$ & $\begin{array}{l}14.23 \\
(1.03)\end{array}$ & $\begin{array}{l}14.19 \\
(1.05)\end{array}$ \\
\hline $\begin{array}{l}\text { Value Added, } \\
\text { growth\% }\end{array}$ & $\begin{array}{c}25.22 \\
(0.87)\end{array}$ & $\begin{array}{l}24.10 \\
(0.72)\end{array}$ & $\begin{array}{l}21.48 \\
(0.68)\end{array}$ & $\begin{array}{l}25.14 \\
(0.66)\end{array}$ & $\begin{array}{l}21.30 \\
(0.80)\end{array}$ & $\begin{array}{l}25.66 \\
(0.89)\end{array}$ & $\begin{array}{l}24.10 \\
(0.77)\end{array}$ & $\begin{array}{l}19.25 \\
(0.72)\end{array}$ \\
\hline Emp, growth\% & $\begin{array}{l}15.64 \\
(0.46)\end{array}$ & $\begin{array}{l}13.54 \\
(0.43)\end{array}$ & $\begin{array}{l}18.34 \\
(0.48)\end{array}$ & $\begin{array}{l}18.02 \\
(0.47)\end{array}$ & $\begin{array}{l}12.53 \\
(0.57)\end{array}$ & $\begin{array}{l}15.91 \\
(0.53)\end{array}$ & $\begin{array}{l}15.63 \\
(0.41)\end{array}$ & $\begin{array}{l}12.86 \\
(0.46)\end{array}$ \\
\hline Human capital & $\begin{array}{r}0.16 \\
(0.25)\end{array}$ & $\begin{array}{r}0.07 \\
(0.19)\end{array}$ & $\begin{array}{r}0.07 \\
(0.18)\end{array}$ & $\begin{array}{r}0.03 \\
(0.11)\end{array}$ & $\begin{array}{r}0.14 \\
(0.23)\end{array}$ & $\begin{array}{r}0.07 \\
(0.16)\end{array}$ & $\begin{array}{r}0.04 \\
(0.11)\end{array}$ & $\begin{array}{r}0.02 \\
(0.08)\end{array}$ \\
\hline Phys capital & $\begin{array}{l}11.43 \\
(2.87)\end{array}$ & $\begin{array}{l}11.31 \\
(3.23)\end{array}$ & $\begin{array}{l}11.81 \\
(2.89)\end{array}$ & $\begin{array}{r}12.30 \\
(2.7)\end{array}$ & $\begin{array}{l}11.18 \\
(4.06)\end{array}$ & $\begin{array}{l}11.35 \\
(3.79)\end{array}$ & $\begin{array}{l}12.02 \\
(2.95)\end{array}$ & $\begin{array}{l}12.33 \\
(3.24)\end{array}$ \\
\hline Emp, log & $\begin{array}{r}1.1 \\
(0.84)\end{array}$ & $\begin{array}{r}0.96 \\
(0.77)\end{array}$ & $\begin{array}{r}0.99 \\
(0.77)\end{array}$ & $\begin{array}{r}1.04 \\
(0.78)\end{array}$ & $\begin{array}{r}1.47 \\
(1.11)\end{array}$ & $\begin{array}{r}1.35 \\
(0.79)\end{array}$ & $\begin{array}{r}1.39 \\
(0.73)\end{array}$ & $\begin{array}{r}1.42 \\
(0.82)\end{array}$ \\
\hline Domestic group & 0.79 & 0.89 & 0.87 & 0.89 & 0.64 & 0.70 & 0.78 & 0.77 \\
\hline Foreign MNE & 0.06 & 0.02 & 0.01 & 0.01 & 0.11 & 0.07 & 0.02 & 0.03 \\
\hline Domestic MNE & 0.03 & 0.02 & 0.01 & 0.01 & 0.08 & 0.06 & 0.02 & 0.04 \\
\hline Domestic indep & 0.12 & 0.07 & 0.11 & 0.08 & 0.17 & 0.17 & 0.17 & 0.16 \\
\hline No. Observations & 1,279 & 722 & 1,658 & 2,854 & 470 & 266 & 619 & 1,204 \\
\hline Unique Firms & 273 & 145 & 346 & 569 & 106 & 65 & 138 & 257 \\
\hline
\end{tabular}


Table 3

Summary statistics. Mean values and standard deviations. Service firms

\begin{tabular}{|c|c|c|c|c|c|c|c|c|}
\hline & \multicolumn{4}{|c|}{ Genuinely New Ventures } & \multicolumn{4}{|c|}{ Spinoffs } \\
\hline & $\begin{array}{l}\text { Metro } \\
\text { cities }\end{array}$ & $\begin{array}{l}\text { Metro } \\
\text { regions }\end{array}$ & $\begin{array}{r}\text { Urban } \\
\text { areas }\end{array}$ & $\begin{array}{l}\text { Rural } \\
\text { areas }\end{array}$ & $\begin{array}{l}\text { Metro } \\
\text { cities }\end{array}$ & $\begin{array}{l}\text { Metro } \\
\text { regions }\end{array}$ & $\begin{array}{r}\text { Urban } \\
\text { areas }\end{array}$ & $\begin{array}{l}\text { Rural } \\
\text { Areas }\end{array}$ \\
\hline Survival & 0.30 & 0.28 & 0.32 & 0.34 & 0.54 & 0.53 & 0.59 & 0.57 \\
\hline Value Added, log & $\begin{array}{l}13.80 \\
(1.17)\end{array}$ & $\begin{array}{l}13.58 \\
(0.99)\end{array}$ & $\begin{array}{l}13.58 \\
(0.99)\end{array}$ & $\begin{array}{l}13.52 \\
(0.95)\end{array}$ & $\begin{array}{r}14.31 \\
(1.19)\end{array}$ & $\begin{array}{l}14.03 \\
(1.04)\end{array}$ & $\begin{array}{l}14.08 \\
(0.99)\end{array}$ & $\begin{array}{l}13.93 \\
(0.96)\end{array}$ \\
\hline $\begin{array}{l}\text { Value Added, } \\
\text { growth\% }\end{array}$ & $\begin{array}{l}24.60 \\
(0.79)\end{array}$ & $\begin{array}{l}20.85 \\
(0.71)\end{array}$ & $\begin{array}{l}23.06 \\
(0.67)\end{array}$ & $\begin{array}{l}19.64 \\
(0.62)\end{array}$ & $\begin{array}{l}25.44 \\
(0.85)\end{array}$ & $\begin{array}{l}20.22 \\
(0.77)\end{array}$ & $\begin{array}{l}22.24 \\
(0.71)\end{array}$ & $\begin{array}{l}19.06 \\
(0.65)\end{array}$ \\
\hline Emp, growth\% & $\begin{array}{l}17.13 \\
(0.52)\end{array}$ & $\begin{array}{l}15.26 \\
(0.48)\end{array}$ & $\begin{array}{l}16.21 \\
(0.46)\end{array}$ & $\begin{array}{l}14.88 \\
(0.46)\end{array}$ & $\begin{array}{l}15.40 \\
(0.52)\end{array}$ & $\begin{array}{l}13.78 \\
(0.48)\end{array}$ & $\begin{array}{r}4.97 \\
(0.48)\end{array}$ & $\begin{array}{l}12.91 \\
(0.46)\end{array}$ \\
\hline Human capital & $\begin{array}{r}0.19 \\
(0.29)\end{array}$ & $\begin{array}{r}0.12 \\
(0.24)\end{array}$ & $\begin{array}{r}0.09 \\
(0.21)\end{array}$ & $\begin{array}{r}0.05 \\
(0.16)\end{array}$ & $\begin{array}{r}0.24 \\
(0.32)\end{array}$ & $\begin{array}{r}0.13 \\
(0.24)\end{array}$ & $\begin{array}{r}0.11 \\
(0.23)\end{array}$ & $\begin{array}{r}0.06 \\
(0.16)\end{array}$ \\
\hline Phys capital & $\begin{array}{l}10.89 \\
(3.53)\end{array}$ & $\begin{array}{l}11.07 \\
(3.25)\end{array}$ & $\begin{array}{l}11.32 \\
(3.07)\end{array}$ & $\begin{array}{l}11.56 \\
(2.93)\end{array}$ & $\begin{array}{l}10.64 \\
(3.91)\end{array}$ & $\begin{array}{l}10.68 \\
(3.97)\end{array}$ & $\begin{array}{l}11.18 \\
(3.47)\end{array}$ & $\begin{array}{l}11.46 \\
(3.44)\end{array}$ \\
\hline Emp, Log & $\begin{array}{r}1.08 \\
(0.86)\end{array}$ & $\begin{array}{r}0.85 \\
(0.76)\end{array}$ & $\begin{array}{r}0.89 \\
(0.74)\end{array}$ & $\begin{array}{r}0.84 \\
(0.73)\end{array}$ & $\begin{array}{r}1.37 \\
(0.80)\end{array}$ & $\begin{array}{r}1.17 \\
(0.76)\end{array}$ & $\begin{array}{r}1.26 \\
(0.74)\end{array}$ & $\begin{array}{r}1.15 \\
(0.72)\end{array}$ \\
\hline Domestic group & 0.81 & 0.90 & 0.89 & 0.92 & 0.70 & 0.79 & 0.82 & 0.86 \\
\hline Foreign MNE & 0.05 & 0.02 & 0.01 & 0.01 & 0.08 & 0.04 & 0.02 & 0.02 \\
\hline Domestic MNE & 0.03 & 0.01 & 0.01 & 0.01 & 0.05 & 0.04 & 0.02 & 0.02 \\
\hline Domestic indep. & 0.11 & 0.07 & 0.09 & 0.06 & 0.17 & 0.13 & 0.14 & 0.10 \\
\hline No. Observations & 22,847 & 12,160 & 19,695 & 20,780 & 6,355 & 2,817 & 5,195 & 4,892 \\
\hline Unique Firms & 5,264 & 2,613 & 4,298 & 4,336 & 1,531 & 701 & 1,234 & 1,164 \\
\hline
\end{tabular}


Table 4

Hazard ratios that new firms will fail for area types, by sectors and technological intensity

\begin{tabular}{|c|c|c|c|c|}
\hline & \multicolumn{2}{|c|}{ Manufacturing } & \multicolumn{2}{|c|}{ Services } \\
\hline & $\begin{array}{l}\text { High and medium } \\
\text { high-tech }\end{array}$ & $\begin{array}{l}\text { Medium-low and } \\
\text { low-tech }\end{array}$ & $\begin{array}{l}\text { High knowledge } \\
\text { intensive }\end{array}$ & $\begin{array}{l}\text { Medium and low } \\
\text { knowledge intensive }\end{array}$ \\
\hline \multicolumn{5}{|c|}{ Genuinely new ventures } \\
\hline \multirow[t]{2}{*}{ Metro cities $^{\mathrm{a}}$} & 0.967 & $1.230 * *$ & $1.166^{* * *}$ & $1.195 * * *$ \\
\hline & $(0.195)$ & $(0.113)$ & $(0.053)$ & $(0.032)$ \\
\hline \multirow[t]{2}{*}{ Metro regions ${ }^{\mathrm{a}}$} & 1.057 & 1.096 & $1.157 * * *$ & $1.059 *$ \\
\hline & $(0.227)$ & $(0.123)$ & $(0.062)$ & $(0.032)$ \\
\hline \multirow[t]{2}{*}{ Urban $\operatorname{rreas}^{\mathrm{a}}$} & 0.877 & 1.032 & $1.101 *$ & $1.105 * * *$ \\
\hline & $(0.164)$ & $(0.087)$ & $(0.055)$ & $(0.029)$ \\
\hline \multicolumn{5}{|l|}{ Spinoffs } \\
\hline \multirow[t]{2}{*}{ Metro cities } & 0.862 & 0.773 & $0.607 * * *$ & $0.590 * * *$ \\
\hline & $(0.238)$ & $(0.128)$ & $(0.040)$ & $(0.037)$ \\
\hline \multirow[t]{2}{*}{ Metro regions } & $0.516^{*}$ & 0.770 & $0.609 * * *$ & $0.567 * * *$ \\
\hline & $(0.193)$ & $(0.174)$ & $(0.063)$ & $(0.044)$ \\
\hline \multirow[t]{2}{*}{ Urban areas } & $0.253 * * *$ & $0.623 * * *$ & $0.494 * * *$ & $0.554 * * *$ \\
\hline & $(0.095)$ & $(0.106)$ & $(0.045)$ & $(0.032)$ \\
\hline \multirow[t]{2}{*}{ Rural areas } & $0.437 * * *$ & $0.698 * * *$ & $0.454 * * *$ & $0.511 * * *$ \\
\hline & $(0.108)$ & $(0.082)$ & $(0.053)$ & $(0.030)$ \\
\hline \multirow[t]{2}{*}{ Emp, Log } & $0.827 * *$ & $0.750 * * *$ & $0.718 * * *$ & $0.706 * * *$ \\
\hline & $(0.067)$ & $(0.030)$ & $(0.014)$ & $(0.009)$ \\
\hline Observations & 1,986 & 7,123 & 27,664 & 67,077 \\
\hline Unique firms & 631 & 2,375 & 9,830 & 22,859 \\
\hline
\end{tabular}

$\underline{\text { Notes }}$

Standard errors in parentheses $* * * \mathrm{p}<0.01, * * \mathrm{p}<0.05, * \mathrm{p}<0.1$

An odds ratio greater than 1 decreases the likelihood of survival. A hazard ratio less than 1 increases the likelihood of survival.

a: Reference is genuinely new ventures in rural areas 
Table 5

Dependent variable: level of value added, GMM

\begin{tabular}{|c|c|c|c|c|}
\hline & \multicolumn{2}{|c|}{ Manufacturing } & \multicolumn{2}{|c|}{ Services } \\
\hline & $\begin{array}{l}\text { High and medium } \\
\text { high-tech }\end{array}$ & $\begin{array}{l}\text { Medium-low and } \\
\text { Low tech }\end{array}$ & $\begin{array}{l}\text { High knowledge } \\
\text { intensive }\end{array}$ & $\begin{array}{c}\text { Medium and low } \\
\text { knowledge intensive }\end{array}$ \\
\hline \multicolumn{5}{|c|}{ Genuinely new ventures } \\
\hline \multirow{2}{*}{ Metro cities $^{\mathrm{a}}$} & 0.076 & 0.012 & 0.066 & -0.000 \\
\hline & $(0.168)$ & $(0.077)$ & $(0.070)$ & $(0.029)$ \\
\hline \multirow[t]{2}{*}{ Metro regions ${ }^{\mathrm{a}}$} & -0.050 & 0.013 & 0.090 & -0.003 \\
\hline & $(0.108)$ & $(0.059)$ & $(0.055)$ & $(0.025)$ \\
\hline \multirow[t]{2}{*}{ Urban $\operatorname{areas}^{\mathrm{a}}$} & -0.011 & 0.036 & 0.020 & 0.015 \\
\hline & $(0.079)$ & $(0.046)$ & $(0.045)$ & $(0.016)$ \\
\hline \multicolumn{5}{|l|}{ Spinoffs } \\
\hline \multirow[t]{2}{*}{ Metro cities } & $0.329 * *$ & $0.209 * *$ & $0.250 * * *$ & $0.140 * * *$ \\
\hline & $(0.139)$ & $(0.098)$ & $(0.077)$ & $(0.046)$ \\
\hline \multirow[t]{2}{*}{ Metro regions } & 0.116 & -0.067 & $0.168 * * *$ & $0.093 * *$ \\
\hline & $(0.145)$ & $(0.087)$ & $(0.064)$ & $(0.045)$ \\
\hline \multirow[t]{2}{*}{ Urban areas } & 0.108 & 0.060 & $0.184 * * *$ & $0.128 * * *$ \\
\hline & $(0.106)$ & $(0.061)$ & $(0.053)$ & $(0.029)$ \\
\hline \multirow[t]{2}{*}{ Rural areas } & 0.061 & 0.034 & $0.237 * * *$ & $0.083 * * *$ \\
\hline & $(0.098)$ & $(0.043)$ & $(0.050)$ & $(0.022)$ \\
\hline \multirow[t]{2}{*}{ Emp, Log } & 0.405 & $1.204 * * *$ & $1.251 * * *$ & $0.907 * * *$ \\
\hline & $(0.258)$ & $(0.165)$ & $(0.209)$ & $(0.134)$ \\
\hline \multirow[t]{2}{*}{ Human capital } & 0.121 & -0.322 & $0.913 * * *$ & $1.074 * * *$ \\
\hline & $(0.651)$ & $(0.389)$ & $(0.308)$ & $(0.319)$ \\
\hline \multirow[t]{2}{*}{ Phys capital } & -0.021 & -0.009 & $0.052 *$ & 0.008 \\
\hline & $(0.041)$ & $(0.030)$ & $(0.027)$ & $(0.028)$ \\
\hline \multirow[t]{2}{*}{ Dom $\mathrm{MNE}^{\mathrm{b}}$} & 0.145 & 0.267 & 0.081 & 0.082 \\
\hline & $(0.202)$ & (0.194) & $(0.064)$ & $(0.073)$ \\
\hline \multirow[t]{2}{*}{ For $\mathrm{MNE}^{\mathrm{b}}$} & $0.285^{*}$ & 0.073 & $0.132 * *$ & $0.257 * * *$ \\
\hline & $(0.157)$ & $(0.189)$ & $(0.056)$ & $(0.050)$ \\
\hline \multirow[t]{2}{*}{ DOM indep. ${ }^{b}$} & -0.050 & $-0.143^{* *}$ & $-0.152 * * *$ & $-0.125^{* * *}$ \\
\hline & $(0.090)$ & $(0.059)$ & $(0.040)$ & $(0.020)$ \\
\hline Observations & 814 & 2,686 & 8,875 & 21,778 \\
\hline Unique Firms & 222 & 712 & 2,274 & 5,532 \\
\hline $\mathrm{AR}(2)$ & 0.972 & 0.392 & 0.381 & 0.571 \\
\hline Hansen Overid & 0.423 & 0.886 & 0.385 & 0.691 \\
\hline Instruments & 69 & 94 & 67 & 57 \\
\hline Lag limits & (3 3) & (3 2) & (3 3) & (3 3) \\
\hline
\end{tabular}

$\underline{\text { Notes }}$

Standard errors in parentheses *** $\mathrm{p}<0.01, * * \mathrm{p}<0.05, * \mathrm{p}<0.1$

Covariates included: human capital, physical capital, firm size, corporate ownership structures, industry dummies and year dummies.

a) Reference is genuinely new firms in rural areas 
b) Reference is domestic firms belonging to a uninational domestic group

Table 6

Dependent variable: growth rate of value added, GMM

\begin{tabular}{|c|c|c|c|c|}
\hline & \multicolumn{2}{|c|}{ Manufacturing } & \multicolumn{2}{|c|}{ Services } \\
\hline & $\begin{array}{l}\text { High and medium } \\
\text { high-tech }\end{array}$ & $\begin{array}{l}\text { Medium-low and } \\
\text { Low tech }\end{array}$ & $\begin{array}{c}\text { High knowledge } \\
\text { intensive }\end{array}$ & $\begin{array}{l}\text { Medium and low } \\
\text { knowledge intensive }\end{array}$ \\
\hline \multicolumn{5}{|c|}{ Genuinely new ventures } \\
\hline \multirow[t]{2}{*}{ Metro cities ${ }^{a}$} & 0.043 & -0.018 & $0.299 * * *$ & $0.058 * * *$ \\
\hline & $(0.093)$ & $(0.047)$ & $(0.067)$ & $(0.016)$ \\
\hline \multirow[t]{2}{*}{ Metro regions $\mathrm{s}^{\mathrm{a}}$} & -0.022 & -0.044 & 0.108 & 0.014 \\
\hline & $(0.069)$ & $(0.049)$ & $(0.072)$ & $(0.014)$ \\
\hline \multirow[t]{2}{*}{ 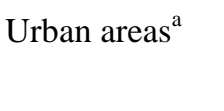 } & -0.083 & -0.016 & 0.101 & $0.024 * *$ \\
\hline & $(0.051)$ & $(0.032)$ & $(0.065)$ & $(0.011)$ \\
\hline \multicolumn{5}{|l|}{ Spinoffs } \\
\hline \multirow[t]{2}{*}{ Metro cities } & 0.145 & -0.040 & $0.433 * * *$ & $0.091 * * *$ \\
\hline & $(0.106)$ & $(0.055)$ & $(0.073)$ & $(0.025)$ \\
\hline \multirow[t]{2}{*}{ Metro regions } & 0.069 & -0.073 & 0.136 & 0.013 \\
\hline & $(0.066)$ & $(0.062)$ & $(0.084)$ & $(0.021)$ \\
\hline \multirow{2}{*}{ Urban areas } & 0.067 & 0.038 & $0.232 * * *$ & $0.074 * * *$ \\
\hline & $(0.058)$ & $(0.046)$ & $(0.071)$ & $(0.019)$ \\
\hline \multirow[t]{2}{*}{ Rural areas } & 0.037 & 0.024 & $0.144^{*}$ & $0.033 * *$ \\
\hline & $(0.052)$ & $(0.035)$ & $(0.085)$ & $(0.015)$ \\
\hline \multirow[t]{2}{*}{ Emp growth } & $0.655^{* * *}$ & $0.655^{* * *}$ & $-0.134 * * *$ & $0.339 * * *$ \\
\hline & $(0.226)$ & $(0.155)$ & $(0.028)$ & $(0.045)$ \\
\hline \multirow[t]{2}{*}{ Human capital } & -0.275 & -0.159 & $0.473 * * *$ & 0.009 \\
\hline & $(0.318)$ & $(0.271)$ & $(0.165)$ & $(0.099)$ \\
\hline \multirow{2}{*}{$\begin{array}{l}\text { Phys capital } \\
\text { growth }\end{array}$} & 0.028 & -0.040 & -0.000 & $0.007 * *$ \\
\hline & $(0.023)$ & $(0.025)$ & $(0.003)$ & $(0.003)$ \\
\hline \multirow[t]{2}{*}{ Dom MNE } & -0.072 & 0.190 & $0.273 * * *$ & $0.141^{* * *}$ \\
\hline & $(0.103)$ & $(0.154)$ & $(0.083)$ & $(0.051)$ \\
\hline \multirow[t]{2}{*}{ For $\mathrm{MNE}^{\mathrm{b}}$} & $0.313 * *$ & $0.229 * *$ & $0.299 * * *$ & $0.133 * * *$ \\
\hline & $(0.146)$ & $(0.112)$ & $(0.080)$ & $(0.039)$ \\
\hline \multirow[t]{2}{*}{ DOM indep. ${ }^{b}$} & -0.091 & $-0.107^{*}$ & $-0.363^{* * *}$ & $-0.126 * * *$ \\
\hline & $(0.058)$ & $(0.059)$ & $(0.037)$ & $(0.027)$ \\
\hline Observations & 814 & 2,686 & 8,875 & 16,329 \\
\hline Unique Firms & 222 & 712 & 2,274 & 5,498 \\
\hline $\mathrm{AR}(2)$ & 0.723 & 0.350 & 0.365 & 0.110 \\
\hline Hansen Overid & 0.365 & 0.215 & 0.041 & - \\
\hline Instruments & 76 & 96 & 107 & 103 \\
\hline Lag limits & $\left(\begin{array}{ll}1 & 1\end{array}\right)$ & $\left(\begin{array}{ll}2 & 1\end{array}\right)$ & $\left(\begin{array}{ll}1 & 2\end{array}\right)$ & $(.)$. \\
\hline
\end{tabular}

Notes

Standard errors in parentheses $* * * \mathrm{p}<0.01, * * \mathrm{p}<0.05, * \mathrm{p}<0.1$ 
Covariates included: human capital, physical capital, Firm size, corporate ownership structure, industry dummies and year dummies.

a) Reference is genuinely new firms in rural areas

b) Reference is domestic firms belonging to a uninational domestic group

Table 7

Dependent variable: growth of labor, GMM

\begin{tabular}{|c|c|c|c|c|}
\hline & \multicolumn{2}{|c|}{ Manufacturing } & \multicolumn{2}{|c|}{ Services } \\
\hline & $\begin{array}{l}\text { High and medium } \\
\text { high-tech }\end{array}$ & $\begin{array}{l}\text { Medium-low and } \\
\text { low tech }\end{array}$ & $\begin{array}{l}\text { High knowledge- } \\
\text { intensive }\end{array}$ & $\begin{array}{c}\text { Medium and low } \\
\text { knowledge- } \\
\text { intensive }\end{array}$ \\
\hline \multicolumn{5}{|c|}{ Genuinely new ventures } \\
\hline \multirow[t]{2}{*}{ Metro cities $^{\mathrm{a}}$} & -0.067 & -0.013 & 0.055 & $0.072 * * *$ \\
\hline & $(0.076)$ & $(0.040)$ & $(0.036)$ & $(0.015)$ \\
\hline \multirow[t]{2}{*}{ Metro regions ${ }^{\mathrm{a}}$} & -0.086 & -0.038 & -0.024 & 0.005 \\
\hline & $(0.073)$ & $(0.047)$ & $(0.037)$ & $(0.015)$ \\
\hline \multirow[t]{2}{*}{ Urban reas $^{\mathrm{a}}$} & 0.022 & -0.008 & 0.017 & 0.012 \\
\hline & $(0.056)$ & $(0.029)$ & $(0.034)$ & $(0.012)$ \\
\hline \multicolumn{5}{|l|}{ Spinoffs } \\
\hline \multirow[t]{2}{*}{ Metro cities } & 0.071 & $-0.110 * *$ & 0.023 & $0.081 * * *$ \\
\hline & $(0.092)$ & $(0.048)$ & $(0.037)$ & $(0.021)$ \\
\hline \multirow[t]{2}{*}{ Metro regions } & -0.023 & $-0.095 *$ & -0.039 & -0.004 \\
\hline & $(0.074)$ & $(0.050)$ & $(0.042)$ & $(0.022)$ \\
\hline \multirow[t]{2}{*}{ Urban areas } & 0.025 & -0.006 & -0.014 & $0.054 * * *$ \\
\hline & $(0.049)$ & $(0.038)$ & $(0.036)$ & $(0.017)$ \\
\hline \multirow[t]{2}{*}{ Rural areas } & -0.061 & -0.007 & $-0.066^{*}$ & 0.007 \\
\hline & $(0.051)$ & $(0.030)$ & $(0.038)$ & $(0.015)$ \\
\hline \multirow[t]{2}{*}{ Human capital } & -0.111 & -0.169 & 0.037 & -0.022 \\
\hline & $(0.260)$ & $(0.201)$ & $(0.088)$ & $(0.081)$ \\
\hline \multirow[t]{2}{*}{ Phys cap. growth } & 0.022 & -0.020 & -0.002 & $0.020 *$ \\
\hline & $(0.014)$ & $(0.025)$ & $(0.017)$ & $(0.011)$ \\
\hline \multirow[t]{2}{*}{ Dom $\mathrm{MNE}^{\mathrm{b}}$} & 0.060 & 0.011 & 0.065 & $0.148 * * *$ \\
\hline & $(0.133)$ & $(0.082)$ & $(0.040)$ & $(0.046)$ \\
\hline \multirow[t]{2}{*}{ For $\mathrm{MNE}^{\mathrm{b}}$} & $0.138 *$ & $0.158 *$ & 0.034 & 0.026 \\
\hline & $(0.082)$ & $(0.083)$ & $(0.041)$ & $(0.030)$ \\
\hline \multirow[t]{2}{*}{ DOM indep. ${ }^{\mathrm{b}}$} & 0.060 & $-0.058 *$ & $-0.110 * * *$ & $-0.086 * * *$ \\
\hline & $(0.046)$ & $(0.033)$ & $(0.023)$ & $(0.017)$ \\
\hline Observations & 814 & 2,686 & 8,875 & 21,778 \\
\hline Unique Firms & 222 & 712 & 2,274 & 5,532 \\
\hline $\operatorname{AR}(2)$ & 0.548 & 0.344 & 0.686 & 0.545 \\
\hline Hansen Overid & 0.149 & 0.128 & 0.128 & 0.193 \\
\hline Instruments & 66 & 67 & 62 & 62 \\
\hline Lag limits & $\left(\begin{array}{ll}1 & 1\end{array}\right)$ & $\left(\begin{array}{ll}1 & 1\end{array}\right)$ & $\left(\begin{array}{ll}1 & 1\end{array}\right)$ & $\left(\begin{array}{ll}1 & 1\end{array}\right)$ \\
\hline
\end{tabular}




\section{$\underline{\text { Notes }}$}

Standard errors in parentheses $* * * \mathrm{p}<0.01, * * \mathrm{p}<0.05, * \mathrm{p}<0.1$

Covariates included: human capital, physical capital, firm size, corporate ownership structures, industry dummies and year dummies.

a) Reference is genuinely new firms in rural areas

b) Reference is domestic firms belonging to a uninational domestic group 